\title{
Performance of lettuce cultivars to protect environmental and soil cover effects
}

\author{
Desempenho de cultivares de alface em condições de ambiente \\ protegido e cobertura do solo
}

Júlio César DoVale ${ }^{1 *}$, Damiana Cleuma de Medeiros ${ }^{2}$

\begin{abstract}
The objective this study was to evaluate protected environment and soil cover effects on the performance of lettuce cultivars in the conditions of semi-arid northeastern Brazil. We used a randomized blocks experimental design with three factors $(2 \times 2 \times 2)$ with four repetitions, totaling eight treatment combinations of two lettuce cultivars (Babá de verão and Primavera de verão), with two conditions of protected environment (with and without agro-textile) and two conditions of soil cover (with and without carnauba straw). The Maravilha de verão cultivar produced three more leaves than the Babá de verão cultivar. In the presence of agro-textile the production cultivars did not differ with or without carnauba straw. However, without agro-textile the cultivars showed differences in production when grown without carnauba straw. This indicates that only one control condition (with agro-textile or with carnauba straw) is sufficient to control weeds and maintain the productive potential of lettuce cultivars.
\end{abstract}

Key words: Lactuca sativa L., yield, greenhouse, carnauba straw.

\section{RESUMO}

O objetivo desse estudo foi avaliar os efeitos do ambiente protegido e da cobertura do solo no desempenho de cultivares de alface em condições do semi-árido nordestino do Brasil. Para isso, foi usado o delineamento em blocos casualizados no esquema fatorial triplo $2 \times 2 \times 2$ com quatro repetições, totalizando 8 tratamentos combinados entre os dois cultivares de alface (Babá de verão e primavera de verão) duas condições de ambiente protegido (com e sem agrotêxtil) e duas condições de cobertura do solo (com e sem palha de carnaúba). O cultivar Maravilha de verão produziu três folhas a mais que o cultivar Babá de verão. Na presença de agrotêxtil, a produção dos cultivares não diferiu com ou sem palha de carnaúba. No entanto, sem agrotêxtil, os cultivares apresentaram diferença na produção quando cultivadas sem o estrato da carnaúba. Isso indica que somente uma condição de controle (com agrotêxtil ou com palha de carnaúba) é suficiente para controlar as plantas daninhas e manter o potencial produtivo dos cultivares de alface.

Palavras chave: Lactuca sativa L., rendimento, casa de vegetação, cera de carnaúba.

\section{Introduction}

Lettuce is one of the most important vegetables cultivated in Brazil both by volume and by commercial value, featuring great acceptance by the consumer (Silva et al., 1995). Planted by great majority of producers in northeast Brazil, it constitutes an important source of income for small farmers.

Soil cover is a cultivation technique that has been used for a long time and in various parts of the world. In Brazil, the northeast region has been highlighting the use of this technique; it is of fundamental importance due to the high temperatures and water deficits in the region. Furthermore, the technique enables the control of weeds, avoiding competition with the crop species. The types of materials used are quite diverse, ranging from straw and grasses to bagasse cane sugar (Puiatti, 1987). Their effect is directly related to the composition of each material.

The lettuce crop in a protected environment significantly reduces the environmental effect caused by some climatic factors such as frost, wind, cold, hail, sunshine and rain. Although the changes that occur in micrometeorological conditions of

\footnotetext{
Universidade Federal de Viçosa, Departamento de Fitotecnia, Avenida P.H. Rolfs, s/no, CEP 36570-000. Viçosa, MG, Brazil. Autor por correspondencia: julio.vale@ufv.br.

2 Universidade Federal do Rio Grande do Norte. Distrito de Jundiaí. CEP 59280-000. Macaíba-RN, Brazil.
}

Fecha de Recepción: 18 Mayo, 2012.

Fecha de Aceptación: 10 Septiembre, 2012. 
protected cultivation are responsible for the proper performance of the crops, not all cultivars adapted to this mode (Farias, 1991).

In this context, the aim of this study is to evaluate the effect of protected environment (with and without agro-textile) and the soil cover effect (with and without carnauba straw) on the performance of lettuce cultivars in the semi-arid conditions of northeast Brazil.

\section{Material and Methods}

The experiment was carried in crop year 2005/06 in an experimental area of the Universidade Federal Rural do Semi-Árido (UFERSA), Mossoró-RN ( $5^{\circ} 11^{\prime} \mathrm{S}$ latitude, $37^{\circ} 20^{\prime} \mathrm{W}$ longitude, and $18 \mathrm{~m}$ elevation), Brazil. According to Köppen, the region's bioclimate is BSwh.

The experimental design was randomized blocks with three factors $(2 \times 2 \times 2)$ with four repetitions, totaling eight treatment combinations of two lettuce cultivars (Babá de verão and Primavera de verão), with two protected environment conditions (with or without agro-textile) and two conditions of soil cover (with or without carnauba straw).

The seeds were sown at a depth of $1 \mathrm{~cm}$ in trays with individual cells, filled with commercial substrate for vegetables. Thinning was carried out seven days after sowing, leaving only one plant per cell. Trays were kept in a greenhouse for 21 days. Irrigations were performed daily (once in the morning and afternoon) as well as foliar fertilization with the commercial compound "Fertamim".

Plots were built to receive lettuce seedlings with the following dimensions: $1.2 \mathrm{~m}$ wide $\mathrm{x} 1.0$ $\mathrm{m}$ long, totaling $1.2 \mathrm{~m}^{2}$ area. The plot consisted of 30 plants. We conducted fertilization at planting, using as nitrogen $(\mathrm{N})$ source $10 \mathrm{~g} \mathrm{plot}^{-1}$ of sulfate of ammonia, phosphorus $\left(\mathrm{P}_{2} \mathrm{O}_{5}\right) 30 \mathrm{~g} \mathrm{plot}^{-1}$ of superphosphate and as a source of potassium $\left(\mathrm{K}_{2} \mathrm{O}\right)$ $6 \mathrm{~g} \mathrm{plot}^{-1}$ of potassium chloride. The seedlings were transplanted and the culture management was performed as recommended for the cultivation of lettuce (Oliveira et al., 2004).

The harvest was performed 26 days after transplanting and considered twelve plants plot $^{-1}$ to carry out statistical analyses. The traits evaluated were number of leaves per plant (NL), plant height $(\mathrm{PH})$, plant diameter (PD), shoot fresh weight (SFW) and shoot dry weight (SDW). All statistical analyses were performed with the computer application in genetics and statistics GENES (Cruz et al., 2006).

\section{Results and Discussion}

There were no significant effects for the conditions protected environment and soil cover conditions for the traits evaluated (Table 1). However, there was a significant $(\mathrm{p}<0.05)$ cultivar effect for the number of leaves. The Maravilha de verão cultivar produced three leaves more than the Babá de verão cultivar.

Table 1. Summary of the analyses of variance for traits number of leaves per plant (NL), plant height (PH), plant diameter (PD), shoot fresh weight (SFW) and shoot dry weight (SDW) evaluated in two lettuce cultivars (Babá de verão and Primavera de verão) combined with two conditions of protected environment (with or without agro-textile) and two conditions of soil cover (with or without carnauba straw) in Mossoró-RN, Brazil, crop year 2005/06.

\begin{tabular}{|c|c|c|c|c|c|c|}
\hline Effect & $\mathrm{DF}$ & $\mathrm{NL}$ & $\mathrm{PH}$ & $\mathrm{PD}$ & SFW & SDW \\
\hline Block & 3 & $18.92 \mathrm{~ns}$ & $12.97 *$ & $13.74 *$ & $55,280^{\mathrm{ns}}$ & $30.11 *$ \\
\hline Cultivar (Cv) & 1 & $72.00 *$ & $2.47^{\mathrm{ns}}$ & $0.53^{\mathrm{ns}}$ & $71,634^{\mathrm{ns}}$ & $3.23^{\mathrm{ns}}$ \\
\hline Agro-textile (At) & 1 & $8.00^{\mathrm{ns}}$ & $6.24^{\mathrm{ns}}$ & $7.90^{\mathrm{ns}}$ & $321,744^{\mathrm{ns}}$ & $0.02^{\mathrm{ns}}$ \\
\hline Soil cover $(\mathrm{Sc})$ & 1 & $0.20^{\mathrm{ns}}$ & $3.53^{\mathrm{ns}}$ & $2.06^{\mathrm{ns}}$ & $12,744^{\mathrm{ns}}$ & $38.11^{\mathrm{ns}}$ \\
\hline At $x \mathrm{Cv}$ & 1 & $11.28^{\mathrm{ns}}$ & $0.18^{\mathrm{ns}}$ & $0.01^{\mathrm{ns}}$ & $33,818^{\mathrm{ns}}$ & $0.03^{\mathrm{ns}}$ \\
\hline At $x \mathrm{Sc}$ & 1 & $8.51^{\mathrm{ns}}$ & $2.89^{\mathrm{ns}}$ & $12.83^{\mathrm{ns}}$ & $363,274 *$ & $3.85^{\mathrm{ns}}$ \\
\hline $\mathrm{Cv} \times \mathrm{Sc}$ & 1 & $6.57^{\mathrm{ns}}$ & $0.82^{\mathrm{ns}}$ & $3.78^{\mathrm{ns}}$ & $8,338^{\mathrm{ns}}$ & $8.04^{\mathrm{ns}}$ \\
\hline At $\times \mathrm{Cv} \times \mathrm{Sc}$ & 1 & $0.63^{\mathrm{ns}}$ & $0.47^{\mathrm{ns}}$ & $3.21 \mathrm{~ns}$ & $105,046^{\mathrm{ns}}$ & $13.70^{\mathrm{ns}}$ \\
\hline Error & 21 & 7.50 & 3.76 & 3.91 & 85,529 & 6.95 \\
\hline Mean & & 26.66 & 16.86 & 23.38 & 1,107 & 15.26 \\
\hline $\mathrm{CV}(\%)$ & & 10.27 & 11.50 & 8.46 & 26.42 & 17.28 \\
\hline
\end{tabular}

$*$ F test significant at $5 \%$ probability, and ${ }^{\mathrm{ns}}$ non-significant. 
Thus, Maravilha de verão cultivar was considered statistically higher than Babá de verão cultivar.

Although it is a trait that directly influences the production of lettuce, in the present study the number of leaves per plant was not sufficient to provide a difference in shoot fresh weight and consequently in shoot dry weight. The magnitude of the coefficients of variation (CV) and means for all traits observed for studies conducted on this lettuce (Oliveira et al., 2004, Carvalho et al., 2005) indicate the reliability of estimates.

The soil cover and agro-textile did not influence the traits plant height and plant diameter. However, for the trait shoot fresh weight there was a significant interaction agro-textile $x$ soil cover. In the presence of agro-textile the production cultivars did not differ with or without carnauba straw (Table 2). However, without agro-textile the cultivars showed a difference in production when grown without carnauba straw. Probably under these conditions there was greater competition with weeds for water, light and nutrients, leading to reduced production of the cultivars. This further indicates that only one control condition (with agro-textile or with carnauba straw) is sufficient to control weeds and maintain the productive potential of lettuce cultivars.
Table 2. Test of means for shoot fresh weight evaluated in two lettuce cultivars (Babá de verão and Primavera de verão) combined with two conditions of protected environment (with or without agro-textile) and two conditions of soil cover (with or without carnauba straw) in Mossoró-RN, Brazil, crop year 2005/06.

\begin{tabular}{lcc}
\hline & $\begin{array}{c}\text { With carnauba } \\
\text { straw }\end{array}$ & $\begin{array}{c}\text { Without carnauba } \\
\text { straw }\end{array}$ \\
\hline With agro-textile & $1,080.84 \mathrm{aA}$ & $1,333.86 \mathrm{aA}$ \\
Without agro-textile & $1,093.40 \mathrm{aA}$ & $920.22 \mathrm{aB}$ \\
\hline
\end{tabular}

Means followed by same letter of the column or the same capital letter in row did not differ by the Scott-Knott test.

\section{Conclusion}

There was no increase in the shoot weight of lettuce cultivars in combination with agro-textile and carnauba straw, because production did not differ significantly when only one of these factors was used. This suggests that the adoption of only one factor (with agro-textile or carnauba straw) is sufficient to permit the lettuce cultivars to express their productive potential.

\section{References}

Carvalho, J.E.; Zanella, F.; Mota, J.H.; Lima, A.L.S. 2005 Cobertura morta do solo no cultivo de alface Cv. Regina 2000, em Ji-Paraná-RO. Ciênc. Agrotec., Lavras, v. 29, n. 5, pp. 935-939.

Cruz, C.D.

2006 Programa GENES: estatística experimental e matrizes. Editora UFV: Vicosa-MG, $480 \mathrm{p}$.

Farias, J.R.B.

1991 Respostas do feijão-vagem à disponibilidade hídrica associada a alterações micrometeorológicas em estufa plástica. Porto Alegre: UFRGS, 177 p.
Oliveira, E.Q.; Bezerra Neto, F.; Negreiros, M.Z.; Barros Júnior, A.P. 2004 Desempenho agroeconômico do bicultivo de alface em sistema solteiro e consorciado com cenoura. Horticultura Brasileira, v. 22, n. 4, pp. 712-717.

Puiatti, M.

1987 Efeito dos resíduos vegetais bagaço de cana-de-açúcar e capim gordura e nitrogênio sobre a cultura do inhame (Colocasia esculenta L. Schott) "chinês". 75f. Tese (Mestrado)-UFV, Viçosa-MG.

Silva, A.C.F.; Rebelo, J.A.; Müller, J.J.V.

1995 Produção de sementes de alface em pequena escala. Agropecuária Catarinense, v. 8, n. 1, pp. 41-44. 
